Article

\title{
Improving Sperm Oxidative Stress and Embryo Quality in Advanced Paternal Age Using Idebenone In Vitro- A Proof-of-Concept Study
}

\author{
Victoria Nikitaras ${ }^{1,2}$, Deirdre Zander-Fox ${ }^{2,3,4,5,6}$ and Nicole O. McPherson 1,2,7,*(D) \\ 1 Robinson Research Institute, University of Adelaide, Adelaide, SA 5005, Australia; \\ victoria.nikitaras@gmail.com \\ 2 Adelaide Health and Medical School, University of Adelaide, Adelaide, SA 5005, Australia; \\ dzander@monashivfgroup.com \\ 3 Repromed, Dulwich, SA 5065, Australia \\ 4 Department of Bioengineering, University of South Australia, Adelaide, SA 5072, Australia \\ 5 Monash University, Clayton, VIC 3800, Australia \\ Monash IVF Group, Richmond, VIC 3168, Australia \\ 7 Freemasons Centre for Male Health and Wellbeing, University of Adelaide, Adelaide, SA 5005, Australia \\ * Correspondence: nicole.mcpherson@adelaide.edu.au; Tel.: +61-883-138-201
}

check for updates

Citation: Nikitaras, V.; Zander-Fox, D.; McPherson, N.O. Improving Sperm Oxidative Stress and Embryo Quality in Advanced Paternal Age Using Idebenone In Vitro-A Proof-of-Concept Study. Antioxidants 2021, 10, 1079. https://doi.org/ 10.3390/antiox10071079

Academic Editors: Branca M. Silva, Marco G. Alves and Pedro F. Oliveira

Received: 2 June 2021

Accepted: 2 July 2021

Published: 5 July 2021

Publisher's Note: MDPI stays neutral with regard to jurisdictional claims in published maps and institutional affiliations.

Copyright: (c) 2021 by the authors. Licensee MDPI, Basel, Switzerland. This article is an open access article distributed under the terms and conditions of the Creative Commons Attribution (CC BY) license (https:// creativecommons.org/licenses/by/ $4.0 /)$.

\begin{abstract}
Advanced paternal age is associated with increased sperm reactive oxygen species (ROS) and decreased fertilization and pregnancy rates. Sperm washing during infertility treatment provides an opportunity to reduce high sperm ROS concentrations associated with advanced paternal age through the addition of idebenone. Sperm from men aged $>40$ years and older CBAF1 mice (12-18 months), were treated with $5 \mu \mathrm{M}$ and $50 \mu \mathrm{M}$ of idebenone and intracellular and superoxide ROS concentrations assessed. Following in vitro fertilization (IVF), embryo development, blastocyst differentiation, DNA damage and cryosurvival, pregnancy and implantation rates and fetal and placental weights were assessed. Five $\mu \mathrm{M}$ of idebenone given to aged human and mouse sperm reduced superoxide concentrations $\sim 20 \%(p<0.05)$, while both 5 and $50 \mu \mathrm{M}$ reduced sperm intracellular ROS concentrations in mice $\sim 30 \%(p<0.05)$. Following IVF, $5 \mu \mathrm{M}$ of idebenone to aged sperm increased fertilization rates $(65 \%$ vs. $60 \%, p<0.05)$, blastocyst total, trophectoderm and inner cell mass cell numbers ( 73 vs. 66,53 vs. 47 and 27 vs. 24 , respectively, $p<0.01$ ). Treatment with idebenone also increased blastocyst cryosurvival rates ( $96 \%$ vs. $78 \%, p<0.01)$ and implantation rates following embryo transfer $(35 \%$ vs. $18 \%, p<0.01)$. Placental weights were smaller (107 mg vs. $138 \mathrm{mg}, p<0.05)$, resulting in a larger fetal to placental weight ratio (8.3 vs. $6.3, p=0.07)$ after sperm idebenone treatment. Increased sperm ROS concentrations associated with advanced paternal age are reduced with the addition of idebenone in vitro, and are associated with improved fertilization rates, embryo quality and implantation rates after IVF.
\end{abstract}

Keywords: reactive oxygen species; male infertility; in vitro fertilization; assisted reproductive technology; male reproduction

\section{Introduction}

The average age of first-time fathers is increasing worldwide. In the past 60 years in Australia, the median age of fathers has increased from 29.0 years to now 33.1 years $(\sim 15 \%)$ [1], with $10 \%$ of all naturally conceived births now coming from fathers $\geq 40$ years [2]. These statistics are heightened within couples seeking assisted reproductive technology (ART) treatment, due to the strong relationship between paternal age and sub-fertility [3-6]. At present, the average age of men undergoing ART in Australia is 38.1 years, with one third of all initiated cycles in men aged $\geq 40$ years [7]. While it is well known that advance maternal age is associated with reduced fertility and a wide variety of reproductive 
complications [8], it is only now becoming apparent that advanced paternal age is also associated with a reduced ability to conceive [3-6] due to its negative associations with sperm parameters (count, motility and morphology) [9] and reproductive hormone levels [10].

More recently, advanced paternal age has been associated with higher levels of semen ROS concentrations and associated sperm DNA damage [11-14]. Oxidative stress is characterized by the overproduction of reactive oxygen species (ROS) including superoxide anions, peroxides and hydroxyl radicals, which outweigh the ROS neutralizing capacity of cellular antioxidant systems [15,16]. Increased oxidative stress results in lipid peroxidation, loss of motility and reduced sperm-oocyte binding [17], along with DNA damage which has been shown to be inherited by the preimplantation embryo and can have negative consequences on pregnancy and offspring health [18]. Sperm require ROS for normal cellular functioning including triggering the signaling cascade for stimulating capacitation, which is a pre-requisite for fertilization [19]. However, as sperm lose the majority of their antioxidant capabilities through cytoplasmic shedding during spermiogenesis, it leaves them vulnerable to oxidative attack [20]. Due to this relative lack of antioxidant protection, sperm are heavily reliant on the surrounding fluid for protection. Seminal plasma contains some of the most highly specialized antioxidants and scavenging enzymes known including glutathione peroxidase (GPx5), extracellular superoxide dismutase (SOD), uric acid, vitamin C, tyrosine and polyphenols [21,22]. However, in standard ART protocol, sperm are washed free of their seminal plasma components to reduce exposure to proteins that inhibit sperm motility and reduce sperm viability (i.e., semenogelin I and II) $[23,24]$. The seminal plasma component is replaced with a culture medium containing carbohydrates, amino acids, buffers, antibiotics and human serum albumin (HSA) with minimal antioxidant properties (i.e., some media contain ETDA and taurine; however, the antioxidant capacity of this is low). The process of sperm washing, therefore, completely removes nearly all the sperm-extrinsic antioxidant components, rendering sperm defenseless to oxidative damage. As sperm are proficient generators of ROS, they are only left with their poorly functioning antioxidant defenses (SOD, GPX and catalase) to combat oxidative damage $[25,26]$. This, coupled with aging, which is already associated with its own reduced antioxidant defenses [27], adds further insult to the already poorly defended sperm.

Antioxidant supplements have been explored as a potential treatment for male infertility, both in vitro and in vivo, as at a cellular level they scavenge ROS and decrease oxidative stress [28-35]. However, very few studies have assessed their benefits in the context of advanced paternal age. A cross-sectional study assessing dietary vitamin C, $E$ and zinc intake in men aged $>44$ years found a $20 \%$ reduction in sperm DNA damage in those men who had the highest micronutrient intake compared with those with the lowest [36], indicating that dietary antioxidants may be beneficial for reducing sperm oxidative stress associated with advanced paternal age. In terms of in vitro antioxidant use, there have been a number of studies assessing whether or not the addition of antioxidants to sperm culture media during human sperm preparation could be beneficial to sperm function [31,37-40], although these studies have not assessed their outcomes in the context of advanced paternal age. While, these studies have shown some beneficial effects to sperm motility, sperm ROS production, lipid peroxidation and sperm viability with the addition of EDTA, lycopene, zinc, ascorbic acid (vitamin C), coenzyme Q10, taurine and glutathione to the medium, little has changed in the composition of current commercial sperm culture medium. One of the biggest limitations of the studies to date is the addition of antioxidants that are not cell-permeable, such as vitamin E and coenzyme Q10, which are instead lipophilic. These tend to be retained in cell membranes and only act via ROS scavenging [41]. Therefore, the positive effects seen in these studies maybe more due to extrinsic ROS removal via antioxidant scavenging as opposed to reducing sperm ROS generation and intrinsic ROS scavenging. Given the fatty acid-rich plasma membrane of sperm, it is vital that the antioxidants added to sperm culture medium are cell-permeable and are capable of reaching the relevant sites of free radical generation such as the mitochondria, which is the primary source of ROS production in sperm [25]. Furthermore, few in vitro 
and in vivo studies have examined the downstream effects on embryo development and pregnancy viability $[28,29,34,42]$, which are required in order to provide an evidence base for prescription and use of antioxidants in clinical practice.

Idebenone is a mitochondrial-permeable synthetic benzoquinone which functions as an antioxidant by scavenging free electrons, as well as acting as a proton and electron carrier in the mitochondrial transport chain, increasing energy production [43-45]. More recently, idebenone has been shown to display molecular activity outside of an antioxidant including bioactivity of idebenone metabolites, protein inhibition (i.e., p52Shc), regulation of gene transcription (i.e., $\operatorname{Lin} 24 A$ ) and reductions in inflammation and endoplasmic reticulum stress [44]. It shares similarities with the antioxidant ubiquinone, known as co-enzyme Q10; however, it is more readily soluble in gamete/embryo-compatible culture media solutions, is able to permeate cellular membranes in vitro and is already been approved by the Therapeutics Goods Administrator (TGA) and US Food and Drug Administration (FDA) to treat Duchenne muscular dystrophy [44], thus making it a good candidate for use in clinical ART. In vitro, idebenone has already been shown to reduce ROS concentrations and cell death in retinal epithelium [46], lipid peroxidation of vascular endothelial cells [47], reduce ROS formation in rat brain synaptosomes [48] and apoptotic cell death in optic nerve astrocytes, all which are hallmark features of oxidative damage and common phenotypes seen in sperm from men of an advanced aged [49]. Therefore, the aim of this proof-ofconcept study was to determine if the addition of a membrane permeable antioxidant (idebenone) to sperm culture media could reduce sperm ROS concentrations associated with advanced paternal age, and define its subsequent effects on fertilization, embryo development and implantation rates utilizing a mouse model of advanced paternal age.

\section{Materials and Methods}

\subsection{Humans and Ethic Approval}

Surplus normozoospermic semen samples (defined by sperm concentration of $\geq 15 \times$ $10^{6} / \mathrm{mL}$ and $\geq 39 \times 10^{6} /$ ejaculate, total sperm motility $\geq 40 \%$ and normal sperm morphology $\geq 4 \%$ [50]) were obtained from seven men over the age of 40 years either undergoing a routine semen analysis or ART procedure at Repromed, a private IVF clinic, in 2018. Men diagnosed with oligo- or azoospermia, or who had a known infectious status, were excluded from the study. Samples were de-identified before they were made available to researchers. Ethical approval was obtained from the University of Adelaide Human Research Ethics Committee (HREC approval number: H-2017-021), as per the Australian National Health and Medical Research Council (NHMRC) Ethical Guidelines. Patient consent was waived by the HREC as involvement in the research carried no more than low risk. Repromeds Scientific Advisory Board also approved the study.

\subsection{Animals and Ethics Approval}

In this study, 12-18-month-old male studs C57BL6 $\times$ CBA (CBAF1) to mimic advanced paternal age [51], pre-pubertal (3-4-week-old) CBAF1 female mice as oocyte donors, 6-month-old vasectomized males CBAF1 to induce pseudo pregnancy and Swiss female mice (7-9-week-old) as recipients for embryo transfer were used. Animals were housed in a temperature-controlled holding room at $21^{\circ} \mathrm{C}$, on a 12:12 h light/dark cycle. All mice were fed standard chow and acidified water ad libitum. The use and care of all animals used in the study was approved by the Animal Ethics Committee of The University of Adelaide (M-2013-119) under the guidance of the Australian Code for the Care and Use of Animals for Scientific Purposes, 8th edition 2013.

\subsection{Culture Media}

For the treatment of sperm with idebenone (Sigma-Aldrich, Castle Hill, New South Wales, Australia), G-IVF PLUS medium (Vitrolife, Denver, CO, USA) was supplemented with either $5 \mu \mathrm{M}$ or $50 \mu \mathrm{M}$ of idebenone, with these concentrations previously been shown to reduce ROS related cellular damage up to $50 \%$ in brain cells and prevent ROS related 
cell death in retinal epithelium [46,48,52,53]. G-IVF PLUS medium was used as a control. For embryo culture, G1.3 PLUS and G2.3 PLUS (Vitrolife) was used. G-IVF PLUS and G1/G2 media were equilibrated at $37{ }^{\circ} \mathrm{C} 6 \% \mathrm{CO}_{2}, 5 \% \mathrm{O}_{2}, 89 \% \mathrm{~N}_{2}$ for $\geq 4 \mathrm{~h}$ prior to use. G-MOPS PLUS handling medium (Vitrolife) was warmed to $37^{\circ} \mathrm{C}$ and used for the transport handling of mouse oocytes, epididymis and embryos. A within-subjects design was used for the assessment of all experiments, such that sperm from one human/mouse was represented across all treatment groups.

\subsection{Isolation of Human Motile Sperm}

To isolate motile sperm fractions that would normally be used for ART insemination, human liquefied semen samples within $1 \mathrm{~h}$ of ejaculation were washed of seminal plasma by a swim-up technique [50]. Whole semen was split into three aliquots and underlaid under $2 \mathrm{~mL}$ of G-IVF PLUS media (control: $0 \mu \mathrm{M}$ ) or G-IVF PLUS medium supplemented with either $5 \mu \mathrm{M}$ or $50 \mu \mathrm{M}$ of idebenone and incubated for $1 \mathrm{~h}$ at $37{ }^{\circ} \mathrm{C} 6 \% \mathrm{CO}_{2}, 5 \% \mathrm{O}_{2}$, $89 \% \mathrm{~N}_{2}$. This is the standard length of time for a swim-up in clinical IVF [50]. Progressively motile sperm were isolated from the top $400 \mu \mathrm{L}$ of medium. All swim-ups contained $\geq 90 \%$ progressively motile sperm and a concentration of $\geq 1 \times 10^{6} / \mathrm{mL}$, which were assessed on a Makler (SEFI-Medical, Haifa, Israel) under $20 \times$ phase contrast light microscopy.

\subsection{Mouse Sperm Collection}

Following euthanasia, sperm from the cauda epididymis and vas deferens were extracted and incubated in G-IVF PLUS (Vitrolife) control medium or G-IVF PLUS medium supplemented with $5 \mu \mathrm{M}$, or $50 \mu \mathrm{M}$ idebenone and incubated for $1 \mathrm{~h}$ at $37^{\circ} \mathrm{C} 6 \% \mathrm{CO}_{2}, 5 \%$ $\mathrm{O}_{2}, 89 \% \mathrm{~N}_{2}$.

\subsection{Sperm Intracellular (DCFDA) and Superoxide ROS (MSR) Assessment}

Sperm $\left(1 \times 10^{6} / \mathrm{mL}\right)$ were assessed for intracellular ROS concentration by incubation with $5 \mu \mathrm{M}$ DCFDA $\left(2^{\prime}, 7^{\prime}\right.$-dichlorodihydrofluorescein diacetate, $\mathrm{H}_{2}$ DCFDA; Life Technologies, Carlsbad, CA, USA) for $60 \mathrm{~min}$ at $37{ }^{\circ} \mathrm{C} 6 \% \mathrm{CO}_{2}, 5 \% \mathrm{O}_{2}, 89 \% \mathrm{~N}_{2}$ and counterstained with $1 \mu \mathrm{M}$ Propidium Iodide (PI) (Sigma-Aldrich) for $5 \mathrm{~min}$ [54]. For assessment of superoxide ROS, sperm were incubated in $5 \mu \mathrm{M}$ MitoSOX Red (MSR, Molecular Probes, Eugene) and $5 \mu \mathrm{M}$ SYTOX Green live/dead counterstain for $30 \mathrm{~min}$ at $37{ }^{\circ} \mathrm{C} 6 \% \mathrm{CO}_{2}, 5 \% \mathrm{O}_{2}, 89 \%$ $\mathrm{N}_{2}$ [55]. Following incubation, samples were washed and suspended in phosphate-buffered saline (PBS) (Sigma-Aldrich) before assessment on a BD FACs Canto II Flow Cytometer (BD Bioscience, North Ryde, Australia), which had CST beads run daily to ensure fluorescence was kept consistent on measurement days. Then, 10,000 cells were examined per sample and non-specific events, including cells identified as positive for PI or SYTOX Green, were gated out. Negative controls were included where sperm were only incubated in either PI or SYTOX Green respectively. The concentrations of ROS for each probe were expressed as the mean fluorescence intensity (fluorescence units) for live cells.

\subsection{Mouse Oocyte Collection and IVF}

Pre-pubertal (3-4-week-old) CBAF1 females were super-ovulated by intra-peritoneal injection of 5IU of Pregnant Mare's Serum Gonadotropin (PMSG; Folligon, Intervet, Bendigo, Australia), followed by injection of 5IU of human chorionic gonadotropin (hCG; Pregnyl; Organon, Oss, The Netherlands) 48 h later. At $12.5 \mathrm{~h}$ post hCG injection, cumulusenclosed oocytes were collected and incubated in $80 \mu \mathrm{L}$ drops of G-IVF PLUS medium (Vitrolife), pre-equilibrated at $37{ }^{\circ} \mathrm{C}: 6 \% \mathrm{CO}_{2} ; 5 \% \mathrm{O}_{2} ; 89 \% \mathrm{~N}_{2}$ under an oil overlay (Ovoil, Vitrolife), before insemination with $1 \times 10^{5} / \mathrm{mL}$ sperm from either control or $5 \mu \mathrm{M}$ idebenone treatment. Prior to insemination, sperm motility was assessed under phase contrast light microscopy classifying 200 spermatozoa as either progressive motile, non-progressively motile or immotile. Gametes were co-incubated for $4 \mathrm{~h}$ at $37{ }^{\circ} \mathrm{C}, 6 \% \mathrm{CO}_{2} ; 5 \% \mathrm{O}_{2} ; 89 \% \mathrm{~N}_{2}$. Following co-incubation, putative zygotes were removed and cultured in $20 \mu \mathrm{L}$ drops of pre-equilibrated G1+ culture medium (Vitrolife), under an oil overlay, for $48 \mathrm{~h}$ at $37^{\circ} \mathrm{C}$ : 
$6 \% \mathrm{CO}_{2} ; 5 \% \mathrm{O}_{2} ; 89 \% \mathrm{~N}_{2}$. Fertilization was assessed at $24 \pm 1.5 \mathrm{~h}$ post-insemination and was identified by cleavage to the 2-cell stage. Embryos were scored for 8-cell development at $48 \pm 1.5 \mathrm{~h}$ post insemination (Day 3 ) and at this stage were transferred to $20 \mu \mathrm{L}$ drops of pre-equilibrated G2 PLUS medium and cultured at $37{ }^{\circ} \mathrm{C}: 6 \% \mathrm{CO}_{2} ; 5 \% \mathrm{O}_{2} ; 89 \% \mathrm{~N}_{2}$ for a further $48 \mathrm{~h}$. At $96 \pm 1.5 \mathrm{~h}$ post-insemination (day 5) blastocyst development was assessed. Blastocysts were categorized as either an early blastocyst (blastocoel cavity $<2 / 3$ of embryo), blastocyst, expanded blastocyst (blastocoel cavity $>2 / 3$ of embryo) or hatching blastocyst (protrusion of the blastocyst through the zona pellucida) [56]. Embryos were then fixed in 4\% paraformaldehyde in PBS (Sigma-Aldrich) or vitrified.

\subsection{Blastocyst Cell Differentiation and Cell Apoptosis Assessments}

Day 5 blastocysts were fixed overnight in $4 \%$ paraformaldehyde (Sigma-Aldrich) at $4{ }^{\circ} \mathrm{C}$ and transferred to $8 \%$ polyvinylpyrrolidone in phosphate-buffered saline (PBS/PVP) the following day. To assess cell differentiation and cellular apoptosis, fixed blastocysts were incubated in $0.1 \mathrm{M}$ glycine in PBS/PVP for $5 \mathrm{~min}$ before they were permeabilized in $0.25 \%$ Triton X-100 (TX) in PBS/PVP (Sigma-Aldrich) for $15 \mathrm{~min}$ at room temperature (RT). Blocking for non-specific antibody binding was achieved by overnight incubation in $10 \%$ Donkey serum in PBS/PVP at $4{ }^{\circ} \mathrm{C}$. The following day, blastocysts were incubated in anti-Oct-4 primary antibody (1:100 dilution in TX; Santa Cruz Biotechnology, Dallas, TX, USA) to assess cell differentiation or anti-active Caspase-3 primary antibody (1:100 dilution in TX; Abcam, Cambridge, UK) for cell apoptosis assessments, for $1.5 \mathrm{~h}$ at $37^{\circ} \mathrm{C}$. This was followed by incubation with Alexa-Fluor donkey anti-goat secondary antibody (1:100 dilution in PBS/PVP; Life Technologies) or Alexa-Fluor 488 donkey anti-rabbit antibody (1:100 dilution in PBS/PVP; Life Technologies) for $2 \mathrm{~h}$ at RT. Blastocysts were counterstained with Hoechst nuclear stain (1:400 dilution in PBS/PVP; Life Technologies) for $5 \mathrm{~min}$ at RT before they were individually mounted onto glass slides using glycerol, and visualized using an Olympus BX51 Epifluorescence Microscope (Olympus America, Center Valley, PA, USA), at 20× magnification and an excitation of 350-510 nm. Cells which were positive for Oct-4 (red) or active Caspase-3 (green) and Hoechst (blue) stains were counted to obtain inner cell mass, apoptotic cells and total cell number, respectively. Trophectoderm cell number was determined by subtracting the number of Oct-4 positive cells from the number of Hoechst-positive cells. For cells to be classified as apoptotic, Caspase-3 (green) had to co-localize with nuclear (Hoechst-blue) staining. Images were taken using SPOT Advanced Software and assessed using Fiji ImageJ [57].

\subsection{Embryo Vitrification and Uterine Transfer}

Following $96 \mathrm{~h}$ of culture (day 5), blastocysts were vitrified using the RapidVit-Blast media system (Vitrolife) in groups of seven or eight, as per the manufacturer's instructions, and stored in liquid nitrogen. The warming of embryos was conducted on the morning of embryo transfer using the Warm-Cleave Media System (Vitrolife). The inserts of the Rapid-I Straws containing the embryos were rapidly submerged into Warm1-Cleave medium for $30 \mathrm{~s}$ followed by the transfer of embryos to Warm2-Cleave, Warm3-Cleave and G-MOPS PLUS handling medium for $1 \mathrm{~min}, 2 \mathrm{~min}$ and 3-5 min, respectively. The embryos were then placed into pre-equilibrated G2 PLUS medium under an oil overlay (Ovoil, Vitrolife) for at least $4 \mathrm{~h}$ at $37^{\circ} \mathrm{C}, 6 \% \mathrm{CO}_{2}, 5 \% \mathrm{O}_{2}, 89 \% \mathrm{~N}_{2}$ prior to embryo transfer to allow for re-expansion. Cryosurvival rates were assessed prior to embryo transfer. Swiss female mice were mated with vasectomized CBAF1 males, and the presence of a copulatory plug was determined on day 1 of pseudopregnancy. At 2.5 days of pseudo-pregnancy, females were anaesthetized with $2 \%$ Avertin (Sigma-Aldrich), before six thawed blastocysts ( $\geq$ expanded blastocyst) from either the control or $5 \mu \mathrm{M}$ idebenone were transferred to contralateral uterine horns of 10 mothers (total of 60 blastocyst per treatment group), meaning that embryos from both treatment groups were gestating in the same mother. On day 18 of gestation, the total number of pregnancies, implantation sites, resorptions and viable fetuses were examined. Fetal and placental lengths/diameters, and weights were measured [17]. 


\subsection{Statistics}

Statistical analysis was performed in SPSS (SPSS Version 18, SPSS Inc., Chicago, IL, USA) or GraphPad Prism (GraphPad Software v6, San Diego, CA, USA). Sperm ROS concentrations, motility and embryo development were analyzed by either a repeated measure ANOVA with a Tukey's multiple comparison test for multiple groups or a paired t-test when comparing only two groups. Embryo cell numbers, apoptosis and blastocyst cryosurvival rates were assessed by a General Linear Model with both treatment group and male fitted as fixed effects and staining/warming day replicate fitted as a covariate. For embryo transfer data, fetal outcomes were analyzed by a univariate GLM, with mother included as a random effect to control for variations to fetal outcomes induced by mother. There was no effect of date of transfer, uterine horn or litter size, and therefore, these were not added to the final model. A $p<0.05$ was considered significant with a $p<0.1$ classified as a trend.

\section{Results}

3.1. Idebenone and Sperm Intracellular and Superoxide ROS Concentrations in Advanced Paernal Age

Seven normospermic men with a mean age of 43 years (range: $41-46$ years) and a mean body mass index of $27.5 \mathrm{~kg} / \mathrm{m}^{2}$ (range: $24.4-30.7 \mathrm{~kg} / \mathrm{m}^{2}$ ) were assessed for both intracellular and superoxide sperm ROS concentrations following incubation in either $0 \mu \mathrm{M}$ (control), $5 \mu \mathrm{M}$ or $50 \mu \mathrm{M}$ of idebenone for $1 \mathrm{~h}$ during sperm washing. Although, there was no effect of idebenone on sperm intracellular ROS concentrations (Figure 1a,b, $p>0.05), 5 \mu \mathrm{M}$ of idebenone reduced sperm superoxide concentrations compared with control $(p<0.001$, Figure $1 \mathrm{c}, \mathrm{d})$ and $50 \mu \mathrm{M}$ of idebenone $(p<0.01$, Figure $1 \mathrm{c}, \mathrm{d})$. Of note, $50 \mu \mathrm{M}$ of idebenone had no effect on sperm superoxide concentrations compared with control $(p>0.05$, Figure $1 c, d)$.

We then wanted to confirm our findings from humans in our advanced paternal age mouse model. In aged male mice, the addition of both $5 \mu \mathrm{M}$ and $50 \mu \mathrm{M}$ idebenone for $1 \mathrm{~h}$ reduced sperm intracellular ROS concentrations compared with control $(p<0.05$, Figure 1e,f). Similar to what was seen in the human, only $5 \mu \mathrm{M}$ of idebenone significantly reduced sperm superoxide concentrations compared with the control $(p<0.01$, Figure $1 \mathrm{~g}, \mathrm{~h})$, although no differences were seen between $5 \mu \mathrm{M}$ and $50 \mu \mathrm{M}$ idebenone $(p>0.05$, Figure $1 \mathrm{~g}$,h). Due to the results seen in humans and mice, we continued to only assess the impact of $5 \mu \mathrm{M}$ of idebenone on sperm for defining subsequent effects on fertilization, embryo development and implantation rates.

\subsection{Idebenone and Fertilization Rates and Embryo Development in a Mouse Model of Advanced Paternal Age}

The addition of $5 \mu \mathrm{M}$ of idebenone to sperm prior to IVF insemination increased the number of progressively motile sperm compared with the control $(p<0.01$, Figure $2 \mathrm{~A})$, which led to an increase in fertilization rates $(p<0.05$, Figure 2B). Sperm superoxide concentrations independent of idebenone treatment were moderately negatively correlated with fertilization rates $(-0.370, p=0.06)$, such that higher sperm superoxide concentrations were associated with a lower fertilization rate. There was no effect of $5 \mu \mathrm{M}$ idebenone on subsequent day 3 on-time development (\% 8-cells) ( $p>0.05$, Figure 2C) or day 5 blastocyst development compared with control ( $p>0.05$, Figure 2D,E).

\subsection{Idebenione and Blastocyst Differentiation and Appoptosis in a Mouse Model of Advanced Paternal Age}

We assessed embryo quality markers of blastocyst cellular differentiation (Oct4 staining) and apoptosis (measured by Caspase 3); $5 \mu \mathrm{M}$ of idebenone to sperm prior to IVF insemination increased blastocyst total cell number $(p<0.001$, Figure $2 \mathrm{~F}, \mathrm{~J})$, trophectoderm cell number $(p<0.01$, Figure $2 \mathrm{G})$ and inner cell mass cell number $(p<0.01$, Figure $2 \mathrm{H})$ compared with the control. We saw no change in the percentage of cells positive for Caspase 3 in the blastocysts due to incubation of sperm with $5 \mu \mathrm{M}$ of idebenone prior to IVF ( $p>0.05$, 
Figure 2I,K), indicating that the increase in cell numbers was not due to a reduction in cellular apoptosis.

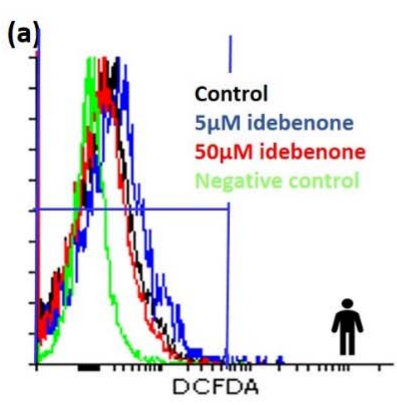

(b)

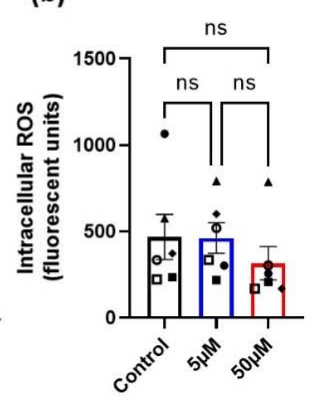

(e)

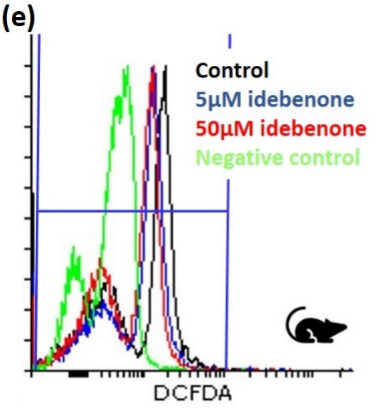

(f)

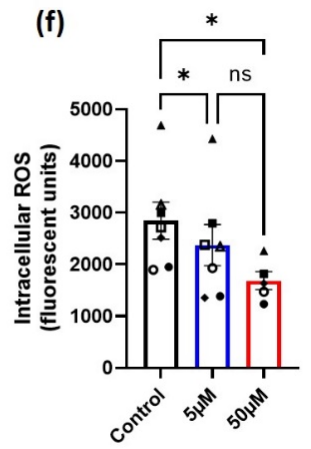

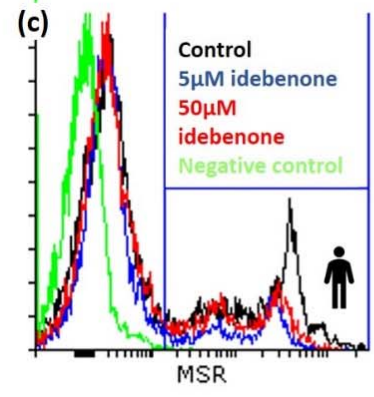

(g)

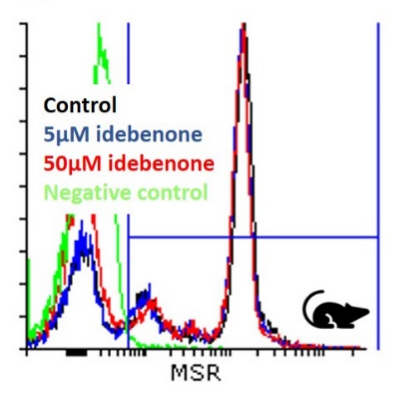

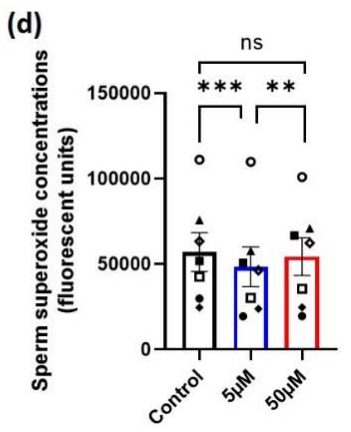

(h)

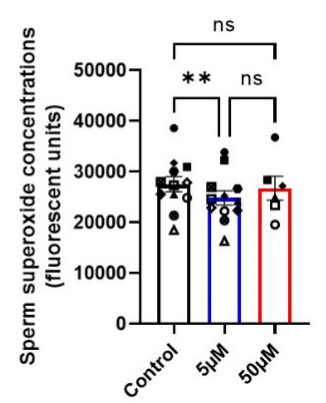

Figure 1. Idebenone in vitro reduces sperm reactive oxygen species concentrations in advanced paternal age. (a) Representative FACS histograms for human sperm for intracellular ROS, (b) Human sperm intracellular ROS concentrations following $1 \mathrm{~h}$ incubation in differing concentrations of idebenone, (c) Representative FACS histograms for human sperm for superoxide, (d) Human sperm superoxide concentrations following $1 \mathrm{~h}$ incubation in differing concentrations of idebenone, (e) Representative FACS histograms for mouse sperm for intracellular ROS, (f) Mouse sperm intracellular ROS concentrations following $1 \mathrm{~h}$ incubation in differing concentrations of idebenone, (g) Representative FACS histograms for mouse sperm for superoxide, (h) Mouse sperm superoxide concentrations following $1 \mathrm{~h}$ incubation in differing concentrations of idebenone. $\mathrm{N}=6$ human sperm biological replications for intracellular ROS and $\mathrm{N}=7$ human sperm biological replicates for superoxide concentrations. $\mathrm{N}=6$ mouse sperm biological replicates for intracellular ROS and $\mathrm{N}=11$ mouse sperm biological replicates for superoxide concentrations. Data were analyzed by a repeated measure ANOVA with a Tukey's multiple comparison test. Different symbol shapes represent the same biological sample; $5 \mu \mathrm{M}-5 \mu \mathrm{M}$ idebenone, $50 \mu \mathrm{M}-50 \mu \mathrm{M}$ idebenone, ns-not significant. ${ }^{*} p<0.05,{ }^{* *} p<0.01,{ }^{* * *} p<0.001$.

3.4. Idebenone and Blastocyst Thaw Survival Rates and Embryo Implantation Rates in a Mouse Model of Advanced Paternal Age

Given the positive benefits of $5 \mu \mathrm{M}$ idebenone to sperm prior to IVF on embryo cell numbers, we then wanted to assess if this would translate to improved implantation and fetal development following embryo transfer. To maximize our embryo transfer protocol and to better mimic procedures that match the ART clinic, we performed blastocyst vitrification and subsequent warming prior to embryo transfer. Note that $5 \mu \mathrm{M}$ of idebenone to sperm prior to IVF insemination increased blastocyst survival rates following embryo warming compared with controls $(p<0.01$, Figure 3a). Although, we saw no difference in the number of mothers that became pregnant between the two groups $(p>0.05$, Figure $3 b)$, $5 \mu \mathrm{M}$ of idebenone to sperm prior to IVF increased the proportion of blastocyst that implanted compared with controls $(p<0.01$, Figure $3 c)$. There was no effect of $5 \mu \mathrm{M}$ of idebenone to sperm prior to IVF on the number of fetuses per implantation, fetal length or fetal weights ( $p>0.05$, Figure $3 \mathrm{~d}-\mathrm{f})$. Interestingly, $5 \mu \mathrm{M}$ of idebenone to sperm prior to IVF insemination reduced placental area $(p=0.07$, Figure $3 g)$ and placental weights $(p<0.05$, Figure 3 h) compared with the control, resulting in an increased fetal-to-placental weight ratio $(p=0.07$, Figure $3 i)$. 

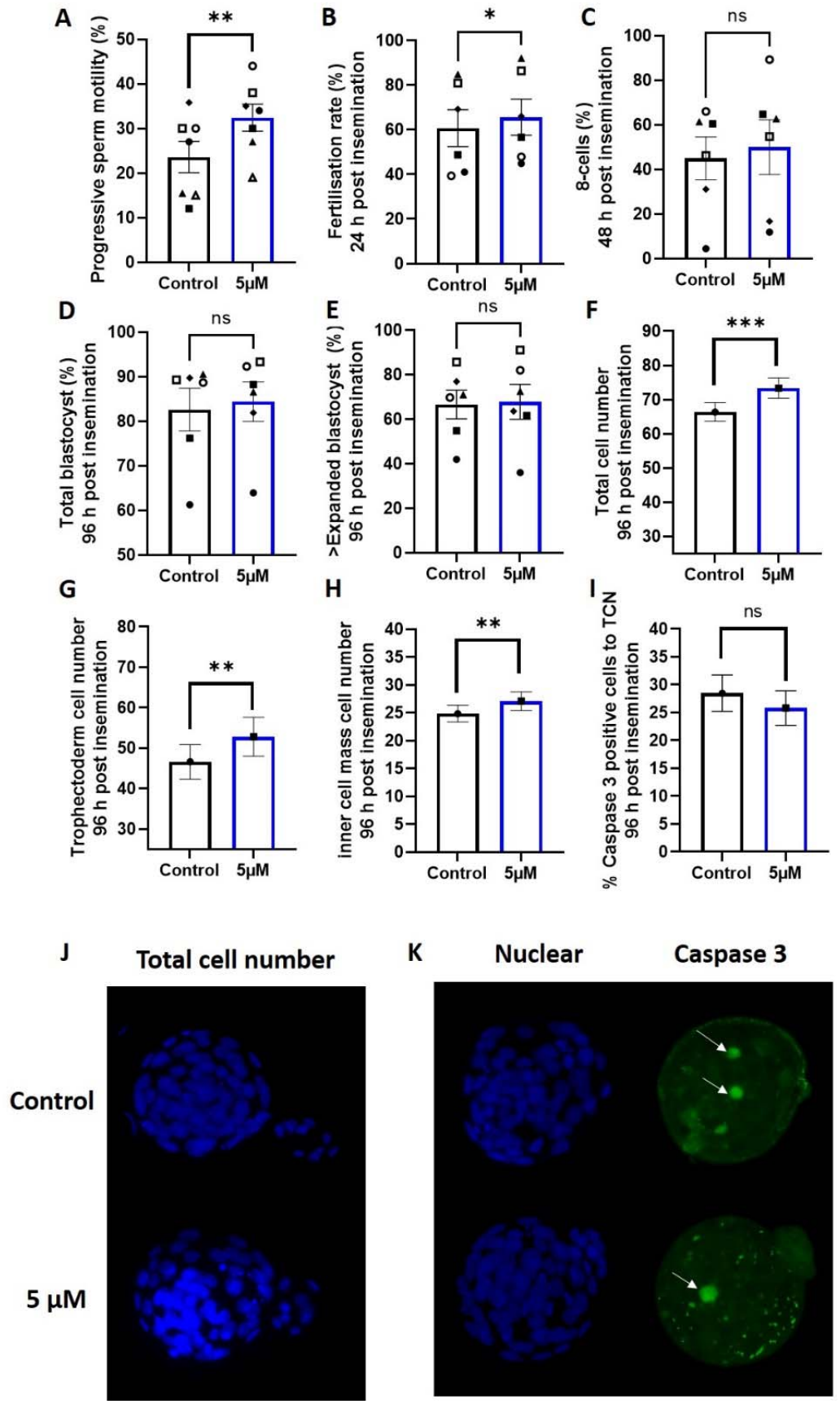

Figure 2. $5 \mu \mathrm{M}$ idebenone in vitro increases sperm motility, fertilization rates and total cell numbers in embryos generated from advanced paternal age. (A) Progressive sperm motility, (B) Fertilization rate from number of MII oocytes inseminated, (C) Percentage of 8 cell embryos $48 \mathrm{~h}$ post insemination from number that fertilized, (D) Total blastocyst ( $\geq$ early blastocyst) $96 \mathrm{~h}$ post insemination from number that fertilized, (E) Percentage of $\geq$ expanded blastocyst (on time) $96 \mathrm{~h}$ post insemination from number that fertilized, (F) Total cell number of blastocyst $96 \mathrm{~h}$ post insemination, (G) Trophectoderm cell number of blastocyst $96 \mathrm{~h}$ post insemination, (H) Inner cell mass cell number of blastocysts $96 \mathrm{~h}$ post insemination, (I) Percentage of caspase 3 positive cells in blastocysts $96 \mathrm{~h}$ post insemination, (J) Representative images of total cell number (blue) for control and $5 \mu \mathrm{M}$ idebenone generated blastocyst $96 \mathrm{~h}$ post insemination and (K) Representative images of Caspase 3 positive staining (green) for control and $5 \mu \mathrm{M}$ idebenone generated blastocysts $96 \mathrm{~h}$ post insemination. $804 \mathrm{control}$ and $7885 \mu \mathrm{M}$ idebenone embryos assessed for embryo morphology from 6 male biological replicates; 32 
control and 27 blastocyst assessed for blastocyst differentiation from 3 male biological replicates and 44 control and $515 \mu \mathrm{M}$ idebenone blastocyst assessed for Caspase 3 from 4 male biological replicates. Different symbol shapes represent the same biological sample. White arrows point to Caspase 3 positive cells. Sperm motility and embryo development were assessed by a paired T-test, while embryo cell numbers and apoptosis were assessed by a General Linear Model with both treatment group and male fitted as fixed effects and staining replicated fitted as a covariate. TCN-Total cell number, $5 \mu \mathrm{M}-5 \mu \mathrm{M}$ idebenone, ns—not significant. ${ }^{*} p<0.05,{ }^{* *} p<0.01$, ${ }^{* * *} p<0.001$.
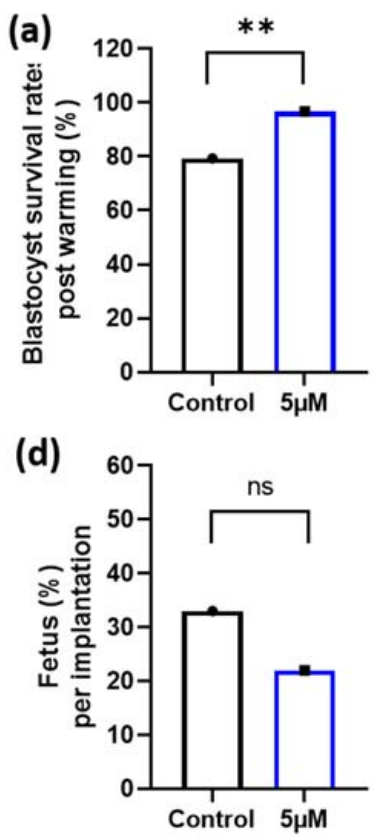

(g)

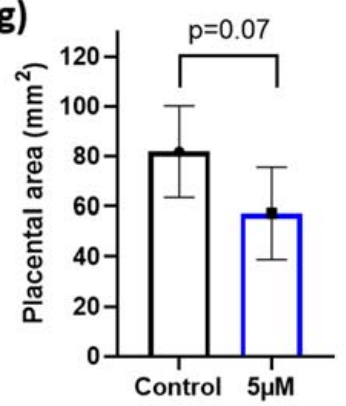

(b)

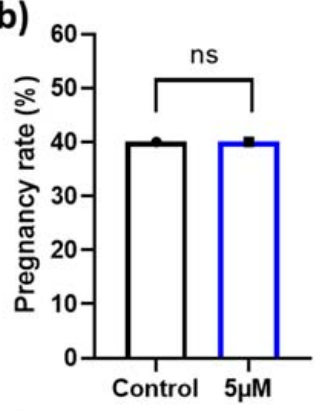

(e)

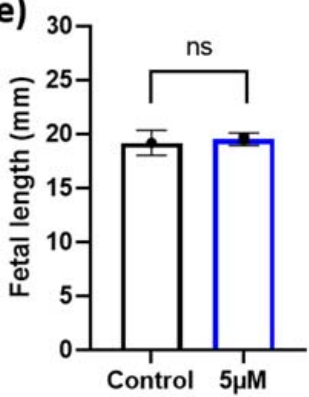

(h)

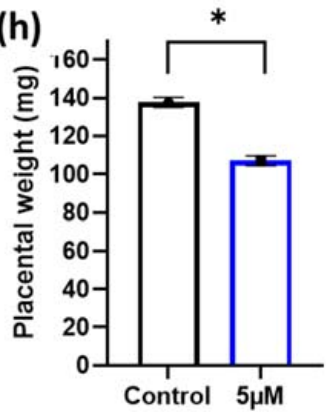

(c)
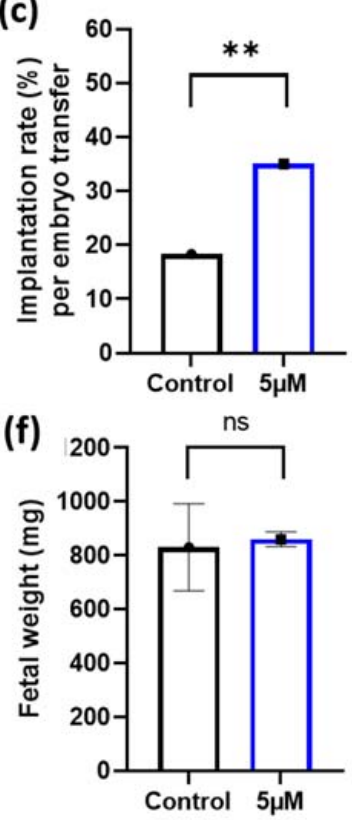

(i)

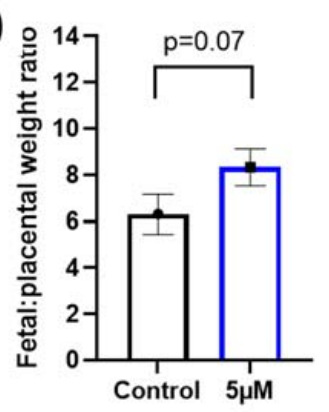

Figure 3. $5 \mu \mathrm{M}$ idebenone in vitro to sperm prior to IVF increases blastocyst thaw survival rates and implantation rates following embryo transfer. (a) Percentage of blastocyst that survived embryo thawing post embryo vitrification, (b) The percentage of pregnant mothers per embryo transfer, (c) The percentage of both resorptions and fetus per embryo transferred, (d) The percentage of fetus per implantation site, (e) Fetal lengths, (f) Fetal weights, (g) Placental area, (h) Placental weight and (i) Fetal placental weight ratios. Blastocyst thaw survival rates represents 92 blastocysts per treatment group. Embryo transfers and pregnancy data is representative of 60 blastocyst per treatment group from 6 male biological replicates transferred into 10 recipient mothers ( 6 blastocyst per treatment group per uterine horn). Blastocyst cryosurvivals were analyzed by a General Linear Model (GLM), with both treatment group and male fitted as fixed effects and warming day fitted as a covariate. Embryo transfer data and fetal outcomes were analyzed by a univariate GLM, with mother included as a random effect to control for variations to fetal outcomes induced by the mother: $5 \mu \mathrm{M}-5 \mu \mathrm{M}$ idebenone, ns-not significant. ${ }^{*} p<0.05,{ }^{* *} p<0.01$. 


\section{Discussions}

While originally it was perceived that male aging had no influence on fertility, we now know that advanced paternal age is associated with subfertility, manifesting as increased time to conception, reduced implantation rates, increased miscarriage rates and reduced live birth rates in both general and ART populations [58,59]. A contributing factor to these poorer fertility outcomes in older men is increased sperm ROS concentrations and associated DNA damage [11-14], which, independently, are linked to reduced pregnancy rates and increased miscarriage rates $[60,61]$. Although, unlike other biological and lifestyle causes of sub fertility, there are limited intervention options that can be used to reverse the effects of biological aging. One potential way to combat increased sperm ROS concentrations associated with advanced paternal age could be through the addition of antioxidants both orally or to sperm culture media prior to IVF. In this proof-of-concept study, we have shown that the addition of idebenone to sperm culture media prior to IVF insemination is able to reduce sperm superoxide ROS concentrations associated with advanced paternal age. This was then associated with an increase in fertilization rates following IVF insemination in mice, increased blastocyst cell numbers, improved blastocyst survival rates following embryo warming and increased implantation rates following embryo transfer, all of which are indicative of better overall embryo quality.

Idebenone was used, due to its chemical similarities to co-enzyme Q10 (a potent antioxidant) as well as its mitochondrial permeability (main source of ROS production in sperm [25]), and its water-soluble properties (making it suitable for use in gamete culture media) [43]. When added to sperm washing media, idebenone was able to reduce sperm ROS concentrations in both males $>40$ years and in our mouse model of advanced paternal age, although there were some slight differences seen between species. For instance, both $5 \mu \mathrm{M}$ and $50 \mu \mathrm{M}$ of idebenone added to mouse sperm were able to reduce hydrogen peroxide and hydroxyl radicals (DCFDA); however, the same result was not seen in humans, while superoxide production in both species was reduced with the addition of $5 \mu \mathrm{M}$ of idebenone. Given that idebenone is labeled as a mitochondrial permeable antioxidant [62], is involved in redox cycling [45] and can scavenge a variety of free radical species with concentrations above $\sim 2 \mu \mathrm{M}$ [45], it was expected that it would be able to reduce superoxide anion production in sperm at $5 \mu \mathrm{M}$. Further, idebenone is also known to have hydrogen peroxide scavenging properties $[63,64]$, which could also explain why it was able to reduce hydrogen peroxide and hydroxyl radicals in the mouse. We believe that the likely reason why mouse sperm were able to reduce both the hydrogen peroxide and hydroxyl radicals, while the same was not seen in humans, was due to the reduced biological and lifestyle variability of research rodents. The mice used, while outbred, were kept in a very controlled research environment limiting other variables (i.e., nutrition) that could modify baseline ROS concentrations, resulting in more consistent results. Although men in this cohort were of an advanced age ( $>40$ years), other biological and lifestyle factors (not obtained) could have resulted in some men having higher baseline ROS concentrations, which may require a higher concentration $(>50 \mu \mathrm{M})$ of idebenone to illicit a reduction in hydrogen peroxide and hydroxyl radicals.

The addition of $5 \mu \mathrm{M}$ idebenone to sperm culture media prior to IVF was associated with improved fertilization rates in our aged mice, with lower fertilizations rates following standard insemination (IVF) a common feature seen in advanced paternal age [58,59,65]. Increased sperm superoxide production coincides with increased formation of lipid aldehyde 4-hydroxynonenal (4HNE) in sperm [66] which is also seen in aging [67]. The formation of $4 \mathrm{HNE}$ can impair the fertilizing capacity of sperm by oxidizing varies surface proteins (i.e., HSPA2) involved in sperm oocyte fusion [68]. This results in a decrease in the number of sperm that can bind to the zona pellucida $[17,69,70]$ and subsequently reduces fertilization. Another way that idebenone may be contributing to the improvements seen in fertilization rates in our mouse model of advanced paternal age is from the benefits seen to sperm progressive motility. In addition to its scavenging antioxidant properties, idebenone also acts as an electron donor to detoxify radicals as well as an aide in ATP production 
once reduced to its hydroquinone form, idebenol, by $\mathrm{NAD}(\mathrm{P}) \mathrm{H}$ quinone oxidoreductase 1 (NQO1) [71]. Sperm contain NAD(P)H quinone oxidoreductase (NQO also known as DTdiaphorase [72,73]) and a sperm-specific enzyme with diaphorase activity [74], suggesting that bioactivation of idebebone can occur within sperm. Idebenone can increase/restore ATP levels under stress conditions with impairments to mitochondrial complex 1 function, by shuttling electrons to complex III of the electron transport chain [63,75]. Mitochondrial energy metabolism is crucial for male reproductive function, with aging associated with reduced mitochondrial respiration rates of sperm [76-78] and decreased sperm motility [9]. Thus, idebenone may be increasing the motility and fertilizing capacity of sperm from older males, potentially via improvements to sperm mitochondrial function and ATP production; however, furthers studies are required to test this.

We were able to also show that the addition of $5 \mu \mathrm{M}$ idebenone to sperm culture media prior to IVF was associated with improve embryo quality as measured by blastocyst cell numbers, blastocyst cryosurvival rates and increased implantation rates following embryo transfer. Blastocyst cell numbers, or the distribution of cells (trophectoderm vs. inner cell mass) within the blastocyst, positively correlates with implantation and pregnancy rates as well as fetal growth $[79,80]$, while cryosurvival of blastocysts is also associated with better embryo quality as only those blastocysts of high quality are able to survive the considerable morpho-functional damage that occurs during cryopreservation and warming [81]. It has already been previously shown that embryos generated (in mice and cattle) from sperm with high ROS concentrations have reduced blastocyst quality (reduced cell numbers and implantation rates) [18,82]. Therefore, the reductions to sperm ROS concentrations due to idebenone could be one possible reason for the improved embryo quality seen in sperm from our aged males. Recently, idebenone has been shown to have additional molecular activity outside that of oxidative damage protection. These include [44]: improved mitochondrial respiration (as discussed above), selective PPAR $\alpha / \gamma$ agonist, inhibition of $\mathrm{p} 52 \mathrm{Shc}$ which acts as an adaptor protein required for a variety of molecular complexes, most notability protein tyrosine kinase receptors (which are vital in sperm capacitation, acrosomal exocytosis and gamete fusion [83]), upregulation of $\operatorname{Lin} 28 \mathrm{~A}$ (although unlikely to be of importance to sperm, due to lack of transcription), reductions to inflammation (commonly seen in aging [84]) and reductions to endoplasmic reticulum stress (again commonly seen in aging [85]). Therefore, improvements to some of these other molecular pathways of aged sperm by idebenone could also be contributing to the associated benefits seen on downstream embryo development and health.

Sperm DNA damage, a major manifestation of oxidative stress and elevated ROS [86-90], is associated with delayed blastocyst development and decreased pregnancy rates [91]. Caspase- 3 is a protein which plays a fundamental role in cellular apoptosis, and may be activated via intrinsic or extrinsic apoptotic pathways [92]. It is present in mouse preimplantation embryos [93], and its activation may be a downstream effect of decreased mitochondrial function and DNA damage, associated with elevated ROS [92,93]. Additionally, idebenone has been shown to suppress levels of active Caspase-3 in human umbilical cord vascular endothelial cells [47] and rat livers [94], and therefore was selected for use as a marker of apoptosis in this study. Whilst the relationship between sperm oxidative stress and apoptosis in the blastocyst had been previously shown [33], our study did not show a reduction in active Caspase-3 positive cells in blastocysts produced from aged sperm with or without $5 \mu \mathrm{M}$ idebenone. A limitation of measuring active Caspase-3 in blastocysts is that it may not be reflective of the sperm DNA damage inherited by the embryo, which may be better detected by gammaH2AX staining or the comet assay. However, given that blastocyst cell numbers were increased in embryos produced from idebenone-treated sperm, it suggests that this increase in cell numbers was more likely due to an increase in cellular division during embryogenesis and not due to a reduction in cellular apoptosis. Further, there is evidence that the quality of the oocyte impacts the ability for it to repair sperm DNA damage at fertilization, with younger oocytes (as seen in our model) able to repair DNA damage at a better rate than aged oocytes [95]. As advanced paternal age tends 
to coincide with advanced maternal age, outcomes may be different if we had utilized aged oocytes in our IVF model.

A higher paternal age at conception has been previously shown to be associated with lower infant birthweight and increased risk of premature birth [96]. In our study, while we saw no effect of $5 \mu \mathrm{M}$ idebenone to sperm prior to IVF on fetal weights and lengths, we did find that idebenone decreased placental weights leading to a trend for increased fetal to placental weight ratios. Fetal-to-placental weight ratios are an important indicator of nutrient transfer from the placenta to the fetus and thus can be used as a surrogate measure of placental efficiency [97], with an increase in fetal-to-placental weight ratio as seen in idebenone-treated sperm associated with upregulated placental nutrient transfer capacity [97]. Interestingly, advanced paternal age at conception is also associated with increased placental weights in humans [96] with high ROS concentrations in sperm also associated with higher placental weights and a decreased fetal-to-placental weight ratios in a mouse model [18]. Therefore, placental modifications due to advanced paternal age at conception could be directly related to increased sperm ROS concentrations, with antioxidants aimed at reducing sperm ROS concentrations prior to fertilization able to improve placental function. This is important, as placental function in utero is directly related to chronic disease risk in adulthood and will be the focus of further studies [98].

This study has also highlighted an important factor that may be contributing to the limited clinical uptake of antioxidants in human sperm culture media, which is that excessive amounts of antioxidants can interfere with physiological ROS concentrations, leading to enhanced ROS generation in mitochondria and further oxidative injury to cells $[99,100]$. In this study, $50 \mu \mathrm{M}$ of idebenone had no effect on sperm superoxide levels in both human and mouse. Previous studies have shown that idebenone can act as a prooxidant through the inhibition of complex 1 of the electron transport chain and an electron acceptor, thereby promoting superoxide production [101-103], with concentrations $>25 \mu \mathrm{M}$ causing apoptosis in human neuronal cell lines in vitro [65]. Therefore, its pro-oxidant properties coupled with a higher concentration (i.e., $50 \mu \mathrm{M}$ ) may have the opposite effect, leading to a state of reductive stress and no change to sperm ROS concentrations $[99,100]$. It is, however, important to note that sperm require a physiologically balanced level of ROS in order to function $[15,16,66]$ and that the dose of antioxidants added to culture media must be carefully considered as they may not be suitable for men with "normal" ROS concentrations and, if used incorrectly, could in fact result in an inhibitory effect [66]. Further, in this study, we only assessed one time point $(1 \mathrm{~h})$ of antioxidant exposure; however, in clinical IVF, sperm can sit in media for up to five hours prior to insemination. Understandingly, antioxidant exposure lengths on sperm quality and function will be important for understanding its true clinical utility.

\section{Conclusions}

This proof-of-concept study has shown that the addition of a cell permeable antioxidant is able to reduce sperm ROS concentrations and is associated with improved subsequent embryo quality in models of advanced paternal age. Further studies to determine the optimal doses, best antioxidant types, exposure length to sperm in vitro, understanding those patients who would benefit the most and downstream consequences to embryo quality and pregnancy outcomes in humans are still required to fully understand whether or not it is plausible and clinically safe to add antioxidants to sperm preparation media.

Author Contributions: Conceptualization, V.N., D.Z.-F. and N.O.M.; data curation, V.N. and N.O.M.; formal analysis, V.N. and N.O.M.; methodology, N.O.M.; supervision, N.O.M.; writing-original draft, V.N. and N.O.M.; writing-review and editing, D.Z.-F. All authors have read and agreed to the published version of the manuscript.

Funding: NOM is the recipient of a Lloyd Cox Research Fellowship.

Institutional Review Board Statement: Human ethical approval was obtained from the University of Adelaide Human Research Ethics Committee (HREC approval number: H-2017-021), as per the 
Australian National Health and Medical Research Council (NHMRC) Ethical Guidelines. The use and care of all animals used in the study was approved by the Animal Ethics Committee of The University of Adelaide (M-2013-119) under the guidance of the Australian Code for the Care and Use of Animals for Scientific Purposes, 8th edition 2013.

Informed Consent Statement: Patient consent was waived by the HREC as involvement in the research carried no more than low risk.

Data Availability Statement: Data availability can be accessed by contacting the corresponding author.

Acknowledgments: The author group would also like to gratefully acknowledge Michelle Lane, who sadly passed away in February 2020, for her advice on the study design.

Conflicts of Interest: DZ is a paid employee of Monash IVF Group Ltd. The company has no role in the design of the study; in the collection, analyses, or interpretation of data; in the writing of the manuscript, or in the decision to publish the results. All other authors declare no conflict of interest.

\section{References}

1. Yun, J.I.; Gong, S.P.; Song, Y.H.; Lee, S.T. Effects of combined antioxidant supplementation on human sperm motility and morphology during sperm manipulation in vitro. Fertil. Steril. 2013, 100, 373-378. [CrossRef]

2. Raad, G.; Mansour, J.; Ibrahim, R.; Azoury, J.; Azoury, J.; Mourad, Y.; Fakih, C.; Azoury, J. What are the effects of vitamin c on sperm functional properties during direct swim-up procedure? Zygote 2019, 27, 1-9. [CrossRef]

3. Szeto, H.H. Mitochondria-targeted peptide antioxidants: Novel neuroprotective agents. AAPS J. 2006, 8, E521-E531. [CrossRef]

4. Truong, T.; Gardner, D.K. Antioxidants improve ivf outcome and subsequent embryo development in the mouse. Hum. Reprod. 2017, 32, 2404-2413. [CrossRef]

5. Gueven, N.; Woolley, K.; Smith, J. Border between natural product and drug: Comparison of the related benzoquinones idebenone and coenzyme q10. Redox Biol. 2015, 4, 289-295. [CrossRef]

6. Gueven, N.; Ravishankar, P.; Eri, R.; Rybalka, E. Idebenone: When an antioxidant is not an antioxidant. Redox Biol. 2021, $38,101812$. [CrossRef]

7. Mordente, A.; Martorana, G.E.; Minotti, G.; Giardina, B. Antioxidant properties of 2,3-dimethoxy-5-methyl-6-(10-hydroxydecyl)1,4-benzoquinone (idebenone). Chem. Res. Toxicol. 1998, 11, 54-63. [CrossRef]

8. Arend, N.; Wertheimer, C.; Laubichler, P.; Wolf, A.; Kampik, A.; Kernt, M. Idebenone prevents oxidative stress, cell death and senescence of retinal pigment epithelium cells by stabilizing bax/bcl-2 ratio. Ophthalmologica 2015, 234, 73-82. [CrossRef]

9. Lin, P.; Liu, J.; Ren, M.; Ji, K.; Li, L.; Zhang, B.; Gong, Y.; Yan, C. Idebenone protects against oxidized low density lipoprotein induced mitochondrial dysfunction in vascular endothelial cells via gsk $3 \beta / \beta$-catenin signalling pathways. Biochem. Biophys. Res. Commun. 2015, 465, 548-555. [CrossRef]

10. Cardoso, S.M.; Pereira, C.; Oliveira, C.R. The protective effect of vitamin e, idebenone and reduced glutathione on free radical mediated injury in rat brain synaptosomes. Biochem. Biophys. Res. Commun. 1998, 246, 703-710. [CrossRef]

11. Vaughan, D.A.; Tirado, E.; Garcia, D.; Datta, V.; Sakkas, D. DNA fragmentation of sperm: A radical examination of the contribution of oxidative stress and age in 16945 semen samples. Hum. Reprod. 2020, 35, 2188-2196. [CrossRef]

12. WHO. Who Laboratory Manual for the Examination and Processing of Human Semen, 5th ed.; Cambridge University Press: Cambridge, UK, 2010.

13. Dutta, S.; Sengupta, P. Men and mice: Relating their ages. Life Sci. 2016, 152, 244-248. [CrossRef] [PubMed]

14. Suno, M.; Nagaoka, A. Inhibition of lipid peroxidation by a novel compound, idebenone (cv-2619). Jpn. J. Pharmacol. 1984, 35, 196-198. [CrossRef]

15. Suno, M.; Nagaoka, A. Inhibition of brain mitochondrial swelling by idebenone. Arch. Gerontol. Geriatr. 1989, 8, 299-305. [CrossRef]

16. Bakos, H.W.; Mitchell, M.; Setchell, B.P.; Lane, M. The effect of paternal diet-induced obesity on sperm function and fertilization in a mouse model. Int. J. Androl. 2011, 34, 402-410. [CrossRef] [PubMed]

17. Koppers, A.J.; Garg, M.L.; Aitken, R.J. Stimulation of mitochondrial reactive oxygen species production by unesterified, unsaturated fatty acids in defective human spermatozoa. Free Radic. Biol. Med. 2010, 48, 112-119. [CrossRef]

18. Gardner, D.K.; Lane, M.; Watson, A.J. A Laboratory Guide to the Mammalian Embryo; Oxford University Press USA-OSO: Cary, NC, USA, 2004.

19. Schindelin, J.; Arganda-Carreras, I.; Frise, E.; Kaynig, V.; Longair, M.; Pietzsch, T.; Preibisch, S.; Rueden, C.; Saalfeld, S.; Schmid, B.; et al. Fiji: An open-source platform for biological-image analysis. Nat. Methods 2012, 9, 676. [CrossRef] [PubMed]

20. Brandt, J.S.; Cruz Ithier, M.A.; Rosen, T.; Ashkinadze, E. Advanced paternal age, infertility, and reproductive risks: A review of the literature. Prenat. Diagn. 2019, 39, 81-87. [CrossRef]

21. McPherson, N.O.; Zander-Fox, D.; Vincent, A.D.; Lane, M. Combined advanced parental age has an additive negative effect on live birth rates-data from 4057 first ivf/icsi cycles. J. Assist. Reprod. Genet. 2018, 35, 279-287. [CrossRef]

22. Kamkar, N.; Ramezanali, F.; Sabbaghian, M. The relationship between sperm DNA fragmentation, free radicals and antioxidant capacity with idiopathic repeated pregnancy loss. Reprod. Biol. 2018, 18, 330-335. [CrossRef] 
23. Cissen, M.; Wely, M.V.; Scholten, I.; Mansell, S.; Bruin, J.P.; Mol, B.W.; Braat, D.; Repping, S.; Hamer, G. Measuring sperm DNA fragmentation and clinical outcomes of medically assisted reproduction: A systematic review and meta-analysis. PLOS ONE 2016, 11, e0165125. [CrossRef]

24. Montenegro, L.; Turnaturi, R.; Parenti, C.; Pasquinucci, L. Idebenone: Novel strategies to improve its systemic and local efficacy. Nanomaterials 2018, 8, 87. [CrossRef]

25. Rauchová, H.; Vrbacký, M.; Bergamini, C.; Fato, R.; Lenaz, G.; Houštěk, J.; Drahota, Z. Inhibition of glycerophosphate-dependent h2o2 generation in brown fat mitochondria by idebenone. Biochem. Biophys. Res. Commun. 2006, 339, 362-366. [CrossRef]

26. Suno, M.; Nagaoka, A. Inhibition of lipid peroxidation by a novel compound (cv-2619) in brain mitochondria and mode of action of the inhibition. Biochem. Biophys. Res. Commun. 1984, 125, 1046-1052. [CrossRef]

27. Halvaei, I.; Litzky, J.; Esfandiari, N. Advanced paternal age: Effects on sperm parameters, assisted reproduction outcomes and offspring health. Reprod. Biol. Endocrinol. 2020, 18, 110. [CrossRef] [PubMed]

28. Wagner, H.; Cheng, J.W.; Ko, E.Y. Role of reactive oxygen species in male infertility: An updated review of literature. Arab. J. Urol. 2018, 16, 35-43. [CrossRef]

29. Zhang, H.; Forman, H.J. 4-hydroxynonenal-mediated signaling and aging. Free Radic. Biol. Med. 2017, 111, 219-225. [CrossRef] [PubMed]

30. Bromfield, E.G.; Aitken, R.J.; McLaughlin, E.A.; Nixon, B. Proteolytic degradation of heat shock protein a2 occurs in response to oxidative stress in male germ cells of the mouse. Mol. Hum. Reprod. 2017, 23, 91-105. [CrossRef] [PubMed]

31. Bromfield, E.G.; Aitken, R.J.; Anderson, A.L.; McLaughlin, E.A.; Nixon, B. The impact of oxidative stress on chaperone-mediated human sperm-egg interaction. Hum. Reprod. 2015, 30, 2597-2613. [CrossRef]

32. Motiei, M.; Tavalaee, M.; Rabiei, F.; Hajihosseini, R.; Nasr-Esfahani, M.H. Evaluation of hspa2 in fertile and infertile individuals. Andrologia 2012, 45, 66-72. [CrossRef]

33. Haefeli, R.H.; Erb, M.; Gemperli, A.C.; Robay, D.; Courdier Fruh, I.; Anklin, C.; Dallmann, R.; Gueven, N. Nqo1-dependent redox cycling of idebenone: Effects on cellular redox potential and energy levels. PLoS ONE 2011, 6, e17963. [CrossRef] [PubMed]

34. Gavella, M.; Lipovac, V. Nadh-dependent oxidoreductase (diaphorase) activity and isozyme pattern of sperm in infertile men. Arch. Androl. 1992, 28, 135-141. [CrossRef]

35. Vasiliou, V.; Ross, D.; Nebert, D.W. Update of the nad(p)h:Quinone oxidoreductase (nqo) gene family. Hum. Genom. 2006, 2, 329-335. [CrossRef] [PubMed]

36. Caldwell, K.; Blake, E.T.; Sensabaugh, G.F. Sperm diaphorase: Genetic polymorphism of a sperm-specific enzyme in man. Science 1976, 191, 1185-1187. [CrossRef]

37. Heitz, F.D.; Erb, M.; Anklin, C.; Robay, D.; Pernet, V.; Gueven, N. Idebenone protects against retinal damage and loss of vision in a mouse model of leber's hereditary optic neuropathy. PLOS ONE 2012, 7, e45182.

38. Sun, N.; Youle, R.J.; Finkel, T. The mitochondrial basis of aging. Mol. Cell 2016, 61, 654-666. [CrossRef] [PubMed]

39. Darr, C.R.; Moraes, L.E.; Scanlan, T.N.; Baumber-Skaife, J.; Loomis, P.R.; Cortopassi, G.A.; Meyers, S.A. Sperm mitochondrial function is affected by stallion age and predicts post-thaw motility. J. Equine Vet. Sci. 2017, 50, 52-61. [CrossRef]

40. Amaral, S.; Ramalho-Santos, J. Aging, mitochondria and male reproductive function. Curr. Aging Sci. 2009, 2, 165-173. [CrossRef] [PubMed]

41. Lane, M.; Gardner, D.K. Differential regulation of mouse embryo development and viability by amino acids. J. Reprod. Fertil. 1997, 109, 153-164. [CrossRef] [PubMed]

42. Lea, R.G.; McCracken, J.E.; McIntyre, S.S.; Smith, W.; Baird, J.D. Disturbed development of the preimplantation embryo in the insulin-dependent diabetic bb/e rat. Diabetes 1996, 45, 1463-1470. [CrossRef]

43. Marsico, T.V.; de Camargo, J.; Valente, R.S.; Sudano, M.J. Embryo competence and cryosurvival: Molecular and cellular features. Anim. Reprod. 2019, 16, 423-439. [CrossRef]

44. Wyck, S.; Herrera, C.; Requena, C.E.; Bittner, L.; Hajkova, P.; Bollwein, H.; Santoro, R. Oxidative stress in sperm affects the epigenetic reprogramming in early embryonic development. Epigenetics Chromatin 2018, 11, 60. [CrossRef]

45. Ijiri, T.W.; Mahbub Hasan, A.K.; Sato, K. Protein-tyrosine kinase signaling in the biological functions associated with sperm. J. Signal. Transduct. 2012, 2012, 181560. [CrossRef] [PubMed]

46. Chung, H.Y.; Kim, D.H.; Lee, E.K.; Chung, K.W.; Chung, S.; Lee, B.; Seo, A.Y.; Chung, J.H.; Jung, Y.S.; Im, E.; et al. Redefining chronic inflammation in aging and age-related diseases: Proposal of the senoinflammation concept. Aging Dis. 2019, 10, 367-382. [CrossRef]

47. Naidoo, N. The endoplasmic reticulum stress response and aging. Rev. Neurosci. 2009, 20, 23-37. [CrossRef]

48. Aitken, R.J.; De Iuliis, G.N.; Finnie, J.M.; Hedges, A.; McLachlan, R.I. Analysis of the relationships between oxidative stress, DNA damage and sperm vitality in a patient population: Development of diagnostic criteria. Hum. Reprod. 2010, 25, 2415-2426. [CrossRef]

49. Aitken, R.J.; Gibb, Z.; Baker, M.A.; Drevet, J.; Gharagozloo, P. Causes and consequences of oxidative stress in spermatozoa. Reprod. Fertil. Dev. 2016, 28, 1-10. [CrossRef] [PubMed]

50. Lewis, S.E.; Aitken, R.J. DNA damage to spermatozoa has impacts on fertilization and pregnancy. Cell Tissue Res. 2005, $322,33-41$. [CrossRef] [PubMed]

51. Aitken, R.J.; De Iuliis, G.N. Origins and consequences of DNA damage in male germ cells. Reprod. Biomed. Online 2007, 14, 727-733. [CrossRef] 
52. Zini, A.; Boman, J.M.; Belzile, E.; Ciampi, A. Sperm DNA damage is associated with an increased risk of pregnancy loss after ivf and icsi: Systematic review and meta-analysis. Hum. Reprod. 2008, 23, 2663-2668. [CrossRef] [PubMed]

53. Simon, L.; Brunborg, G.; Stevenson, M.; Lutton, D.; McManus, J.; Lewis, S.E.M. Clinical significance of sperm DNA damage in assisted reproduction outcome. Hum. Reprod. 2010, 25, 1594-1608. [CrossRef]

54. Chen, L.; Gong, M.-W.; Peng, Z.-F.; Zhou, T.; Ying, M.-G.; Zheng, Q.-H.; Liu, Q.-Y.; Zhang, Q.-Q. The marine fungal metabolite, dicitrinone b, induces a375 cell apoptosis through the ros-related caspase pathway. Mar. Drugs 2014, 12, 1939-1958. [CrossRef] [PubMed]

55. Spanos, S.; Rice, S.; Karagiannis, P.; Taylor, D.; Becker, D.; Winston, R.; Hardy, K. Caspase activity and expression of cell death genes during development of human preimplantation embryos. J. Reprod. 2002, 124, 353-363. [CrossRef]

56. Fadda, L.M.; Hagar, H.; Mohamed, A.M.; Ali, H.M. Quercetin and idebenone ameliorate oxidative stress, inflammation, DNA damage, and apoptosis induced by titanium dioxide nanoparticles in rat liver. Dose Response 2018, 16. [CrossRef] [PubMed]

57. Lord, T.; Aitken, R.J. Fertilization stimulates 8-hydroxy-2'-deoxyguanosine repair and antioxidant activity to prevent mutagenesis in the embryo. Dev. Biol. 2015, 406, 1-13. [CrossRef]

58. Khandwala, Y.S.; Baker, V.L.; Shaw, G.M.; Stevenson, D.K.; Lu, Y.; Eisenberg, M.L. Association of paternal age with perinatal outcomes between 2007 and 2016 in the united states: Population based cohort study. BMJ 2018, 363, k4372. [CrossRef] [PubMed]

59. Hayward, C.E.; Lean, S.; Sibley, C.P.; Jones, R.L.; Wareing, M.; Greenwood, S.L.; Dilworth, M.R. Placental adaptation: What can we learn from birthweight:Placental weight ratio? Front. Physiol. 2016, 7, 28. [CrossRef] [PubMed]

60. Thornburg, K.L.; Marshall, N. The placenta is the center of the chronic disease universe. Am. J. Obstet. Gynecol. 2015, 213, S14-S20. [CrossRef] [PubMed]

61. Chen, S.-J.; Allam, J.-P.; Duan, Y.-G.; Haidl, G. Influence of reactive oxygen species on human sperm functions and fertilizing capacity including therapeutical approaches. Arch. Gynecol. Obs. 2013, 288, 191-199. [CrossRef]

62. Bisht, S.; Dada, R. Oxidative stress: Major executioner in disease pathology, role in sperm DNA damage and preventive strategies. Front. Biosci. (Sch. Ed.) 2017, 9, 420-447.

63. Jaber, S.; Polster, B.M. Idebenone and neuroprotection: Antioxidant, pro-oxidant, or electron carrier? J. Bioenerg. Biomembr. 2015, 47, 111-118. [CrossRef] [PubMed]

64. Genova, M.L.; Ventura, B.; Giuliano, G.; Bovina, C.; Formiggini, G.; Parenti Castelli, G.; Lenaz, G. The site of production of superoxide radical in mitochondrial complex $\mathrm{i}$ is not a bound ubisemiquinone but presumably iron-sulfur cluster $\mathrm{n} 2$. FEBS Lett. 2001, 505, 364-368. [CrossRef]

65. Tai, K.-K.; Pham, L.; Truong, D.D. Idebenone induces apoptotic cell death in the human dopaminergic neuroblastoma shsy-5y cells. Neurotox. Res. 2011, 20, 321. [CrossRef]

66. Aitken, R.J.; Baker, M.A. Causes and consequences of apoptosis in spermatozoa; contributions to infertility and impacts on development. Int. J. Dev. Biol. 2013, 57, 265-272. [CrossRef] [PubMed]

67. ABS. Births, Australia, 2010; Australian Bureau of Statistics: Canberra, Australia, 2010.

68. AIHW. Australian Insitute of Health and Welfare. Australias Health: Canberra, Australia, 2012.

69. Belloc, S.; Hazout, A.; Zini, A.; Merviel, P.; Cabry, R.; Chahine, H.; Copin, H.; Benkhalifa, M. How to overcome male infertility after 40: Influence of paternal age on fertility. Maturitas 2014, 78, 22-29. [CrossRef] [PubMed]

70. Ford, W.C.; North, K.; Taylor, H.; Farrow, A.; Hull, M.G.; Golding, J. Increasing paternal age is associated with delayed conception in a large population of fertile couples: Evidence for declining fecundity in older men. The alspac study team (avon longitudinal study of pregnancy and childhood). Hum. Reprod. 2000, 15, 1703-1708. [CrossRef] [PubMed]

71. Mathieu, C.; Ecochard, R.; Bied, V.; Lornage, J.; Czyba, J.C. Cumulative conception rate following intrauterine artificial insemination with husband's spermatozoa: Influence of husband's age. Hum. Reprod. 1995, 10, 1090-1097. [CrossRef] [PubMed]

72. Belloc, S.; Cohen-Bacrie, P.; Benkhalifa, M.; Cohen-Bacrie, M.; De Mouzon, J.; Hazout, A.; Menezo, Y. Effect of maternal and paternal age on pregnancy and miscarriage rates after intrauterine insemination. Reprod. Biomed. Online 2008, 17, 392-397. [CrossRef]

73. Newman, J.; Paul, R.; Chambers, G.M. Assisted Reproductive Technology in Australia and New Zealand 2018; The University of New South Wales: Sydney, Australia, 2020.

74. Sauer, M.V. Reproduction at an advanced maternal age and maternal health. Fertil. Steril. 2015, 103, 1136-1143. [CrossRef]

75. Kidd, S.A.; Eskenazi, B.; Wyrobek, A.J. Effects of male age on semen quality and fertility: A review of the literature. Fertil. Steril. 2001, 75, 237-248. [CrossRef]

76. Bhasin, S.; Gagliano-Juca, T.; Huang, G.; Basaria, S. Age-related changes in the male reproductive system. In Endotext; Feingold, K.R., Anawalt, B., Boyce, A., Chrousos, G., de Herder, W.W., Dhatariya, K., Dungan, K., Grossman, A., Hershman, J.M., Hofland, J., et al., Eds.; South Dartmouth: Dartmouth, MA, USA, 2000.

77. Rosiak-Gill, A.; Gill, K.; Jakubik, J.; Fraczek, M.; Patorski, L.; Gaczarzewicz, D.; Kurzawa, R.; Kurpisz, M.; Piasecka, M. Age-related changes in human sperm DNA integrity. Aging (Albany NY) 2019, 11, 5399-5411. [CrossRef]

78. Tremellen, K. Oxidative stress and male infertility-A clinical perspective. Hum. Reprod. Update 2008, 14, 243-258. [CrossRef] [PubMed]

79. Cocuzza, M.; Athayde, K.S.; Agarwal, A.; Sharma, R.; Pagani, R.; Lucon, A.M.; Srougi, M.; Hallak, J. Age-related increase of reactive oxygen species in neat semen in healthy fertile men. Urology 2008, 71, 490-494. [CrossRef] [PubMed] 
80. Nago, M.; Arichi, A.; Omura, N.; Iwashita, Y.; Kawamura, T.; Yumura, Y. Aging increases oxidative stress in semen. Investig. Clin. Urol. 2021, 62, 233-238. [CrossRef] [PubMed]

81. Walczak-Jedrzejowska, R.; Wolski, J.K.; Slowikowska-Hilczer, J. The role of oxidative stress and antioxidants in male fertility. Cent. Eur. J. Urol. 2013, 66, 60-67. [CrossRef] [PubMed]

82. Ko, E.Y.; Sabanegh, E.S.; Agarwal, A. Male infertility testing: Reactive oxygen species and antioxidant capacity. Fertil. Steril. 2014, 102, 1518-1527. [CrossRef] [PubMed]

83. Redgrove, K.A.; Nixon, B.; Baker, M.A.; Hetherington, L.; Baker, G.; Liu, D.Y.; Aitken, R.J. The molecular chaperone hspa2 plays a key role in regulating the expression of sperm surface receptors that mediate sperm-egg recognition. PLoS ONE 2012, 7, e50851. [CrossRef]

84. Lane, M.; McPherson, N.O.; Fullston, T.; Spillane, M.; Sandeman, L.; Kang, W.X.; Zander-Fox, D.L. Oxidative stress in mouse sperm impairs embryo development, fetal growth and alters adiposity and glucose regulation in female offspring.(research article). PLoS ONE 2014, 9, 1-9. [CrossRef]

85. Aitken, J.; Fisher, H. Reactive oxygen species generation and human spermatozoa: The balance of benefit and risk. BioEssays News Rev. Mol. Cell. Dev. Biol. 1994, 16, 259-267. [CrossRef] [PubMed]

86. Aitken, R.J.; Curry, B.J. Redox regulation of human sperm function: From the physiological control of sperm capacitation to the etiology of infertility and DNA damage in the germ line. Antioxid Redox Signal. 2011, 14, 367-381. [CrossRef]

87. Aitken, R.J. Gpx5 protects the family jewels. J. Clin. Investig. 2009, 119, 1849-1851. [CrossRef]

88. Rhemrev, J.P.; van Overveld, F.W.; Haenen, G.R.; Teerlink, T.; Bast, A.; Vermeiden, J.P. Quantification of the nonenzymatic fast and slow trap in a postaddition assay in human seminal plasma and the antioxidant contributions of various seminal compounds. $J$. Androl. 2000, 21, 913-920.

89. Murakami, J.; Yoshiike, M.; Satoh, M.; Furuichi, Y.; Iwamoto, T. Characterization of recombinant precursor proteins of the human seminal plasma sperm motility inhibitor synthesized in insect cells. Int. J. Mol. Med. 1998, 2, 693-700. [CrossRef]

90. Yoshida, K.; Yamasaki, T.; Yoshiike, M.; Takano, S.; Sato, I.; Iwamoto, T. Quantification of seminal plasma motility inhibitor/semenogelin in human seminal plasma. J. Androl. 2003, 24, 878-884. [CrossRef] [PubMed]

91. Aitken, R.J.; Buckingham, D.W.; Carreras, A.; Irvine, D.S. Superoxide dismutase in human sperm suspensions: Relationship with cellular composition, oxidative stress, and sperm function. Free Radic. Biol. Med. 1996, 21, 495-504. [CrossRef]

92. Williams, A.C.; Ford, W.C. Functional significance of the pentose phosphate pathway and glutathione reductase in the antioxidant defenses of human sperm. Biol. Reprod. 2004, 71, 1309-1316. [CrossRef] [PubMed]

93. Schoneich, C. Reactive oxygen species and biological aging: A mechanistic approach. Exp. Gerontol. 1999, 34, 19-34. [CrossRef]

94. Ross, C.; Morriss, A.; Khairy, M.; Khalaf, Y.; Braude, P.; Coomarasamy, A.; El-Toukhy, T. A systematic review of the effect of oral antioxidants on male infertility. Reprod. Biomed. Online 2010, 20, 711-723. [CrossRef]

95. Showell, M.G.; Mackenzie-Proctor, R.; Brown, J.; Yazdani, A.; Stankiewicz, M.T.; Hart, R.J. Antioxidants for male subfertility. Cochrane Database Syst. Rev. 2014, 12. [CrossRef] [PubMed]

96. Ahmadi, S.; Bashiri, R.; Ghadiri-Anari, A.; Nadjarzadeh, A. Antioxidant supplements and semen parameters: An evidence based review. Int. J. Reprod. Biomed. 2016, 14, 729-736. [CrossRef]

97. Chi, H.J.; Kim, J.H.; Ryu, C.S.; Lee, J.Y.; Park, J.S.; Chung, D.Y.; Choi, S.Y.; Kim, M.H.; Chun, E.K.; Roh, S.I. Protective effect of antioxidant supplementation in sperm-preparation medium against oxidative stress in human spermatozoa. Hum. Reprod. 2008, 23, 1023-1028. [CrossRef] [PubMed]

98. Talevi, R.; Barbato, V.; Fiorentino, I.; Braun, S.; Longobardi, S.; Gualtieri, R. Protective effects of in vitro treatment with zinc, d-aspartate and coenzyme q10 on human sperm motility, lipid peroxidation and DNA fragmentation. Reprod. Biol. Endocrinol. 2013, 11, 81. [CrossRef] [PubMed]

99. Gualtieri, R.; Barbato, V.; Fiorentino, I.; Braun, S.; Rizos, D.; Longobardi, S.; Talevi, R. Treatment with zinc, d-aspartate, and coenzyme q10 protects bull sperm against damage and improves their ability to support embryo development. Theriogenology 2014, 82, 592-598. [CrossRef]

100. Barbato, V.; Talevi, R.; Braun, S.; Merolla, A.; Sudhakaran, S.; Longobardi, S.; Gualtieri, R. Supplementation of sperm media with zinc, d-aspartate and co-enzyme q10 protects bull sperm against exogenous oxidative stress and improves their ability to support embryo development. Zygote 2017, 25, 168-175. [CrossRef] [PubMed]

101. Gharagozloo, P.; Aitken, R.J. The role of sperm oxidative stress in male infertility and the significance of oral antioxidant therapy. Hum. Reprod. 2011, 26, 1628-1640. [CrossRef]

102. Schmid, T.E.; Eskenazi, B.; Marchetti, F.; Young, S.; Weldon, R.H.; Baumgartner, A.; Anderson, D.; Wyrobek, A.J. Micronutrients intake is associated with improved sperm DNA quality in older men. Fertil. Steril. 2012, 98, 1130-1137 e1131. [CrossRef]

103. Zini, A.; San Gabriel, M.; Libman, J. Lycopene supplementation in vitro can protect human sperm deoxyribonucleic acid from oxidative damage. Fertil. Steril. 2010, 94, 1033-1036. [CrossRef] 